\title{
芳香族ボリエステル-アミドおよびポリエステル・ヒドラジトの 耐光性と難燃性
}

\author{
田中 伊都郎*1 渡辺 一难*2 ・加藤 克彦*3
}

(受付 1978 作 12 月 27 日・棤李終了 1979 年5月 21 日)

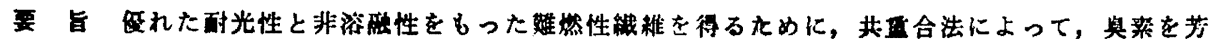

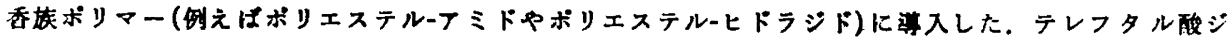
クロリド,インフタル酸ジヒドラシドと 2,2-ビス (3,5-ジブロモ-4ヒドロキシフニェル)プロパン[テ

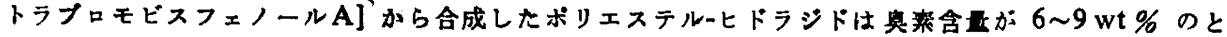
き，满足できる性能を有し，算れた衣料用の锥然性轼維として使用できる可能性のあることがわかっ

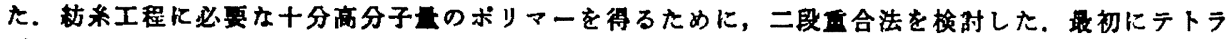
ブロモビスフェノールAとテレフタル酸ジロリドをハログン化炭化水桨溚媒中で反応させ，次いで

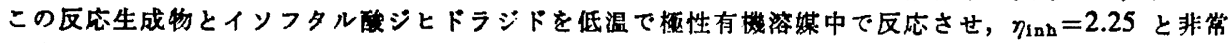
に高粘度のポリエステルヒドラジドが得られた。
\end{abstract}

\section{1. 楮霉}

全芳香族ボリフミドは，難然性，非洛能性であって，

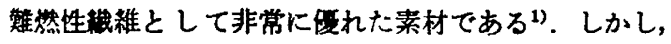

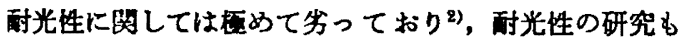
行われているが》，本質的な解決には至らず，全芳香族

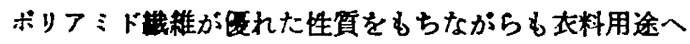
の展閉の道が閉さされているのか実状である.

前報けで指摘し心ように，若香族ボリフミトに打いて， ベンゼン核にアミド基の窒辢原子が直結していると, 光 照射による黄変を故けることが非常にむずかしい，した がって，奶策としてペンゼン核と空菜原子を分離すると， 㢦光性は改良される. しかし, 難然性や非溶融性が逆に 悪くなり好ましくなかった。

こういった背量のもとに本研究では，耐光性の辰れた 非溶融性で，しかも自己消火性の素材の開発を目的とし た. 研究の進め方として, 非溶愿性にするには芳香族禾 ポリマーが好ましく，更に成形性を考皇ると，ボリェス テル系よりポリフミド系の方が好ましい．したがってポ リマーの基本標造としては、ベンゼン核にアミド基の空

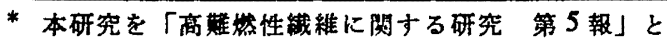
ナろ.

*1 宩洋紡績（株）東京支店（-103 東京都中央区日本 橋小絧町 17-9)

*2 東洋紡䋖（株）䌊合研究所（-1520-02 大津市堅田町 1300-1)

*3 東洋紡織 (株) 東洋紡ニューヨーク年狢所 (245 Park Avenue, New York, N.Y. 10017 U.S.A.)
菜原子が直結していない（1)，(2) 式に示されるよらな

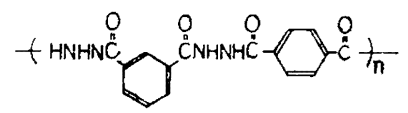

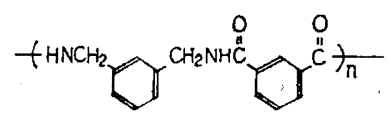

芳香族ボリヒドラジドや芳香族ポリフミドを用いて，こ れらに難然性を付与する方向で领討した.

知然性を付与する方法としては，後加工法，ブレンド 改留，共重合といった方法が考えられるが，耐久性に传 れ風合いゃ性といった問題点の少ないと考えられる共 重合法を採用し，難然性を付与する元萦としてよく知ら れている臭秦の導入について梌討を行った。

導入方法としては，化学的に安定で入手しゃすい，八 ロゲン化ビスフェノールを用いて (3) 式に示すような, 芳香族ポリエステルーヒドラシドなどの合成を行い，難然

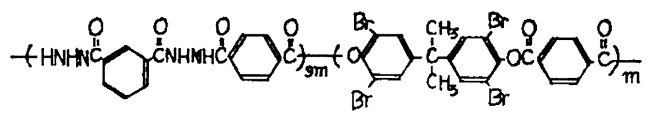

(3)

性と耐光性の共に優れた索村の探索を行い，更に最適組 成の共重合体に関し高重合度化の検討を行った。 


\section{2 实}

2.1 原料

\subsection{1 モノマー}

モノマーはイソフタロイルジヒドラジドを文献跑裁の 方法りで合成したはかは市肘品を常法に佂い蒸留，再結 晶法により精製したものを使用した。

モノマーの名称と略号および腡点（または沸点）の実 测檤と文献値のを示す（）内ぶ文献佔

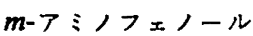

\begin{tabular}{|c|c|}
\hline (MAP) & $\mathrm{mp} 123 \sim 124^{\circ} \mathrm{C}($ \\
\hline $\begin{array}{l}m \text {-キシリレンジフ :ン } \\
(\mathrm{MXD})\end{array}$ & $\begin{array}{l}\text { bp } 140 \sim 142^{\circ} \mathrm{C} / 14 \mathrm{~m} \\
140^{\circ} \mathrm{C} / 14 \mathrm{mmHg}\end{array}$ \\
\hline p-キシリレンジアミン & \\
\hline (PXD) & $\mathrm{mp} 36 \sim 37^{\circ} \mathrm{C}\left(35^{\circ} \mathrm{C}\right)$ \\
\hline 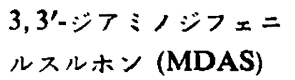 & $\operatorname{mp~} 169 \sim 170^{\circ} \mathrm{C}$ \\
\hline $4,4^{\prime}$-ジフミノジフェニ & \\
\hline ルメタン (PAPM) & $\mathrm{mp} 91 \sim 92^{\circ} \mathrm{C}\left(93^{\circ} \mathrm{C}\right)$ \\
\hline ピペラジン (PIPZ) & $\mathrm{mp} 103 \sim 104^{\circ} \mathrm{C}\left(104^{\circ} \mathrm{C}\right.$ \\
\hline イソフタロイルジヒド & \\
\hline ラジド (IPDH) & $234 \sim 235^{\circ} \mathrm{C}\left(225.6^{\circ} \mathrm{C}\right)$ \\
\hline
\end{tabular}

元秉分析値. Calcd: C, 49.48; H, 5.19; N, 28.85 .

Found: C, $49.50 ; \mathrm{H}, 5.27$; N. 28.90.

テレフタル酸ジクロリド (TPC) $\mathrm{mp} 83.5^{\circ} \mathrm{C}\left(81 \sim 82^{\circ} \mathrm{C}\right)$

インフタル酸ジクロド (IPC) $\mathrm{mp} 45^{\circ} \mathrm{C}\left(42 \sim 43^{\circ} \mathrm{C}\right)$

2,2-ピス(3,5-ジプロモ-4ヒドロキシフェニル)プロハ ข (TBA) $\mathrm{mp} 190^{\circ} \mathrm{C}$

元素分析値. Calcd: C, 33.12; H, 2.22; Br, 58.77.

Found: C, 33.45; H, 2.23; Br, 57.78. ビス(3,5-ジブロモ-4とドロキシフェニル)スルホン

(TBS)

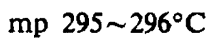

元策分析何. Calcd: C, 25.47; H, 1.07; Br, 56.49;

$$
\text { S, } 5.65 \text {. }
$$

Found: C, 25.43; H, 1.22; $\mathrm{Br}, 56.42$; S, 5.65 .

2,2-ピス[3,5-ジブロモ-4-(2-ヒドロキシェトキシ)フェ ニルプロハン (HTBA) mp $108 \sim 110^{\circ} \mathrm{C}$ ハイドロキノン (HQ) $\operatorname{mp~} 170^{\circ} \mathrm{C}\left(169^{\circ} \mathrm{C}\right)$

2,2-ビス(4-ヒドロキシフェニル)プロハン (BA)

$\operatorname{mp~} 156^{\circ} \mathrm{C}\left(154^{\circ} \mathrm{C}\right)$

なお，代装的なハロダン化ビスフェノールの揣造式 を次に示しておく。

TBA

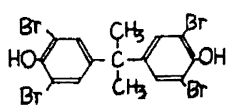

TBS

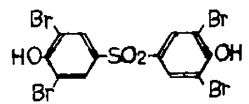

HTBA

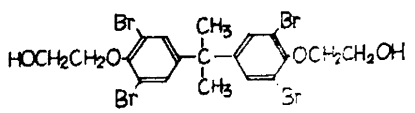

\subsection{2 その他}

重合溶媒，酸受容剤はいずれも市肘品を常法に従って 精製した。

2.2 ポリマーの合成

ポリエステルーフミドの合成は重合溶媒の $N$ イメチル-2ピロリドン (NMP) に所定量のジフミンとビスフェノー 儿成分を均一に溶解し，理論発生塩酸摬亡等モルの酸受 容剂を添加し， $0^{\circ} \mathrm{C}$ に冷印，激しくかきませ゚ながら酸ク ロリトを一時に粉末状で添加し， $0^{\circ} \mathrm{C} て 1$ 時間，次い で室温で5時间かくはんして重合を完結し，得られたボ リマー浴液を多量の水の中に入れてポリーーを析出さ せ, ミキサーで粉啸，水洗して減圧乾燥した。

一方，ボリェステルーヒドラジドについては上記の方 法でポリマーを合成し, 耐光性, 雉然性つ検捨を行い, 最も好ましい組成のものに関し，更に獄重合度でしかも 均一透明な重合溶液を得るために, 次の (4)，(5) 式に示 す2段車合法で合成した。
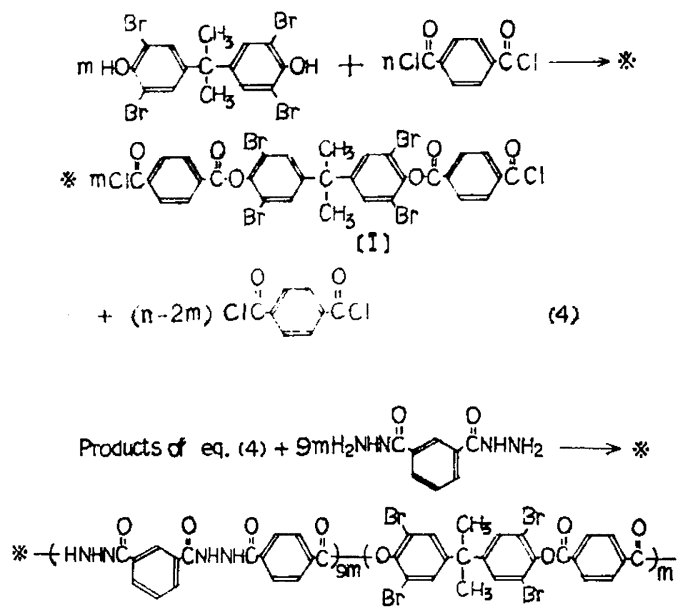

(5)

この実駼操作の概要は下図のようこ行った。

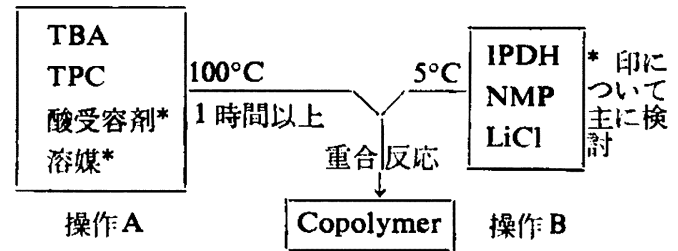


すなわち，(4) 式に相当する操作Aでは，空素置渙し た容器に所定要の TBA と TPCを入れ，客媒を加えて 加温する，系が均一になったところで計算量の醊受容郕 を添加する（生成する塩酸と当モル量が好ましい），更 に $100^{\circ} \mathrm{C} て ゙ 1$ 時間反応させる.

一方，操作Bでは，四つロフラスコに勒嬠した $\mathrm{LiCl}$ を入れ、ベーキングを行った後 IPDH を添加し，窒素

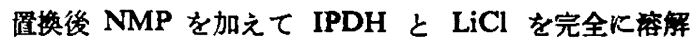
させ, 米浴で 0 $5^{\circ} \mathrm{C}$ に合却する.

次いで (5) 式に示すよ5に操作 Aの反応混合物を室 温付近まで邻却したものを，操作 B で得られた IPDH 溶液中に敏しくかきまぜながら添加して重合反応を開始 する.手内岋すく温度が $30^{\circ} \mathrm{C} く$ ぐいまで上昇し,5 10 分で粘性が高まり始め，2時間ぐらいで重合は完了 し，無色ないし钽黄色の透明なボリマー溶夜が得られた。

\section{3 ポリマーの性罱}

\subsection{1 ホリマー敲度}

ボリェステルーアミド 5 wt\%の LiClを含をDMAC, ポリエステルーヒドラジドばチルスルホキシド (DMSO) を容媒とし, $0.5 \mathrm{~g} / 100 \mathrm{ml}, 30^{\circ} \mathrm{C}$ で対数粘度 放的求めた。

\subsection{2 ボリマー槽造の破铝}

得られたボリマーの槽造および共重合体の組成分析は 元素分析，IR，TG などにより確贸した.

\subsection{3 㐨然性}

難然性の評価としては，マッチテスト，極限酸素指数 (LOI) 法を用いた。最䔔な組成の探索段階は簡単なマッ チテストで可然性が自己消火性か，および火源に接した とき溶融するか否かを钼察し，試料は $30 \sim 50 \mathrm{~g} / \mathrm{m}^{2}$ 程度 のフィルムを用いた．また， LOI の测定には前報》に述 べた方法で洰纸状の試科を作り，同一目付での值を求め て相互比慗梌討を行った。

\subsection{4 酎光世}

フェードオメーター 40 時間照射を行い, 照射前後の 色調の变化を锤察し，涌光性の良否を判定した，等級を 5級から1彶まで5段陵に分けて，次のよらにした。

5 級：全く色の变化が認められない

4 級：かすかに微黄色に変色する

3 級：淡黄色湾色する

2 級：黄色下変色する

1 趿：浱い黄色ないし茶色に変色する

衣料用途として考えるときK必要な等級は悪くても4 級で，好ましくは5級であると考えられるので，本研究 の目票は5級とした。

\section{3 塻果と考寀}

\section{1 苴合}

\subsection{1一段萳合}

一段重合の場合でも $\eta_{\mathrm{tan}}=1.0$ とかなりの重合度のも
のが得られたが，再現性にそしいことと，紡系に供する にはまた十分とはいいがたいままた，IPDH-T のホモポ リマーの場合は酸受容剮がなくてもよいが，コポリマー の場合は TPC 添加のまえに, ピリジンなどの酸受容㓮 を副生する塩酸と当モ儿量添加する必要があった．

酸受容郕としてはピりジンが最も適当で， $\mathrm{p} K_{\mathrm{a}}$ 值のよ り大きなトリェチルフミン, $N$-ィチルモルホリンなどで はゲル化が起こり好ましくなかった。

一段重合で好ましくないのは，重合の再現性がそしい 点以上に，重合体溶液が白濁してくる点であり，この傾 向はビスフェノール成分が $7 \mathrm{~mol} \%$ で少し見られ，10 mol％ではかなり增加する。この原因は酸クロリドに 対するフミノ基と水酸基の反応性の差によると考えられ るので, 次の二段重合法について検討した。

\subsection{2 二段正合}

一段目の反応山 TBA の 2 倍モルの TPCを使用する よりも大過利に用いる方が反応が円滑に進行し，最終ポ リマーの粘度も高かった，なお，(4) 式で化合物 (I)を 単離して，これと TPC を所定量の比率で IPDH と重 合しても高分子量のポリマーが生成したが，単離操作， 精製が非常に複雑で侕格的に考えると (I) の単離は好 ましくないであろう，溶媒については，TPC に不活性 であるテトラクロロエタン,クロロホルムといったハロ ゲン化炭化水素がよい，無溶媒では TPC の昇華が起こ ク，好ましくない，溶媒が多すぎると次の (5) 式の重合 反応でポリマーが析出して好ましくなかった，次に酸受 容脷は不可欠で，ビリジンが最も好ましかった。

二段目の反応 (5) 式は全く通常の低温溶液重合と同じ 方法で行らことができた.

\section{2 ボリマー模造の㼛認}

代表的ポリマーとして，ビスフェノール成分が TBA $10 \mathrm{~mol} \%$ ，ジヒドラジト成分が IPDH $90 \mathrm{~mol} \%$ の組 成で TPC との共重合体 [TBA/IPDH (1/9)-T と表示 するにについて検討した，一段重合で得られたボリマー の臭秦の元素分析値は $8.86 \mathrm{wt} \%$ で，計算値の 8.89 wt \% とよく一致しており，仕込比と実際に生成したボ リマー組成はほぼ一致していた，次にこのポリマーを NMP に溶解し，水を添加していき，析出してくる順に 三つのフラクション I, II, III に分別し, その重量割合 と臭素の含量を分析したところ次のよらになった。

\begin{tabular}{cccc}
\hline & & 重量割合 $(\mathrm{wt} \%)$ & 臭菜含有量 $(\mathrm{wt} \%)$ \\
\hline フラクション & I & 6 & 19 \\
" & II & 80 & 8 \\
" & III & 5 & 5 \\
\hline
\end{tabular}

また，IR 分析では $1700 \mathrm{~cm}^{-1}$ のエステル結合に基つ く棵収が I から III に従って弱くなっていた. 上記結 果より，コポリマーはェステル成分の多い低分子量の成 
田中・波辺・加藤

Table 1. Synthesis and properties of aromatic polyester-amides

\begin{tabular}{|c|c|c|c|c|c|c|}
\hline \multicolumn{3}{|c|}{ Polymer structure ${ }^{n}$} & \multirow[b]{2}{*}{$\begin{array}{l}\eta_{\ln }{ }^{b)} \\
(\mathrm{d} l / g)\end{array}$} & \multirow{2}{*}{ Polymer solution } & \multicolumn{2}{|c|}{ Properties } \\
\hline Diamine & Bisphenol & $\begin{array}{c}\text { Acid } \\
\text { chloride }\end{array}$ & & & Flammabilityc) & Light-fastness $^{d)}$ \\
\hline PIPZ & TBS & IPC & $\left.0.95^{\circ}\right)$ & Pale brown clear & SE & 3 \\
\hline , & TBA &, & $1.06^{\circ)}$ & " & SE & 3 \\
\hline MXD & TBS & " & 0.19 & Colorless clear & SE $\left.^{\prime}\right)$ & 2 \\
\hline$n$ & $n$ & TPC & 0.35 & Pale yellow clear & $\mathrm{SE}^{\prime)}$ & $1 \sim 2$ \\
\hline$"$ & TBA & $"$ & 0.32 & Colorless clear & $S E^{r)}$ & $2 \sim 3$ \\
\hline PXD & TBS & , & insol. & Slightly white turbid & - & - \\
\hline MDAS & , & " & 0.46 & Pale brown clear & SE & 2 \\
\hline MAP & " & " & 0.22 & Colorless clear & $S E^{f)}$ & $1 \sim 2$ \\
\hline " & " & TPC & 0.24 & Pale yellow clear & $\mathrm{SE}^{\mathrm{P})}$ & $1 \sim 2$ \\
\hline PAPM & $"$ & IPC & 0.24 & Colorless clear & SE & 1 \\
\hline , & " & TPC & 0.90 & Pale yellow clear & SE & 1 \\
\hline
\end{tabular}

a) Mole ratio of diamine/bisphenol was $9 / 1$. b) $0.5 \mathrm{~g} / 100 \mathrm{ml}$ in DMAC (containing $5 w \mathrm{Lt} \% \mathrm{LiCl}$ ) at $30^{\circ} \mathrm{C}$.

a) Determined by match test. SE means self-extinguishing. d) The number shows the grade of lightfastness (fade-O-meter $40 \mathrm{~h}$ ). 1, dark yellow or brown; 2, yellow; 3, light yellow; 4, pale yellow; 5 , no change. Original samples were white. ") $96 \% \mathrm{H}_{2} \mathrm{SO}_{4}$ was used as solvent. ") The sample melted partially without dripping.

分を少し含み、これが白濁の原因と推定される.

一方，二段重合法においては，反応式 (4) で $m / n=$ 1/2 のときの生成物の元素分析値 [C, 42.43 (42.45); H, 2.14 (2.07)； 八ロゲン, 44.21 (44.53), ただし（）内

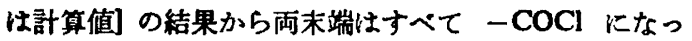
ていると判断できるので, ボリエステルとボリヒドラシ ドの混合物ではなく，ランダムコボリマーと考えられ ろ.

事実，二段重合の埸合，白濁むなく，均一透明な高粘 度のボリマー溶液が得られ， $\mathrm{Br}$ の元茶分析値も实测值 と計筑値が注は致していた (Table 3 参照).

その他のボリマーについても個々に検討していないが TBA/IPDH (1/9)-T とほぼ同棣と推定した。

\section{3 ボリエステルーアミトの合成と平価}

ジアミン成分として耐光性が良好と予想されるピベ ジン, PXD, MXD, MDAS, MAP と比较の意味で PAPM を用い, ビスフェノール成分としてTBA, TBS, を用いて重合した結果を Table 1 に示す. ジフンと ビスフェノールの仕込みモル比はすぺて 9 対 1 で, Brの 含有胃は計算值ではほ 8 12 wt \% である. 重合方法は 一段重合法のため，重合度はあまり高くないが，一部の ボリマーを除いて十分柔軟性のあるフィルムが生成した ので耐光性と奞然性の評価を行らには十分と判断した。

Table 1 の結果から明らかなよらに,ビスフェノール 成分の TBS と TBA ではポリマーの性質にほとんど差 は認められない. 酸クロリドに闺してはTPC の方が重 合度は上がりやすいが，ポリマーに着色が生じやすく， 预光性もやや劣っている. $\mathrm{Br}$ を 8 12 wt \% 含むこれ
らのボリェステルーフミドはすべて自己消火性を示し， 解然性は满足できる。しかし，MXD，MAP に閶して は火源に接したとき，滴下することはないが少し溶歌す る㑯向があり, 非溶融性とい5目的からはやや好ましく ない.

TBA と MAP から合成されたボリエステルーアミド は荍然性，耐光性に比れているといら報告》があるが解 光性はあまり良くない. MAP の場合, 黄変の程度は全 芳香族ボリアミドに比へると良好であるが，フミノ基が ベンセン核に值結している部分が半分近くあり，エステ ル結合を少し蒙入してる大幅な改善はできていない。一 方アアミノ基がペンゼン核と雜れているときは良好な酎 光性を示している. なかでるビペラジンを用いた场合，

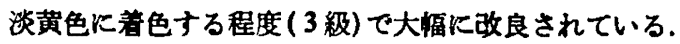
本実段の結果，耐光性が十分とはいえないけれどす全体 的にみて，ほぼ満足できる索材として，ピベラシンと TBA（または TBS）を用いたボリマー組成が見いたさ れた.

\section{4 ホリエステルーヒトラジトの合成と两俩}

ジヒドラジトとしてインフタロイルジヒドラジドを用 いて稹々のビスフェノールとの組合せによってボリェス テルーヒドラジドを合成した結果を Table 2 に示す.

Table 2 から明らかなよらに，重合は一段重合法なの で重合度はあまり高くないが，ジチルスルホキシド溶 液から乾式法で無色适明の柔軟なフィルムが生成した。

耐光性は全芳香族ボリフミドや芳香族ボリェステルー フミドに比べてはるかに传れており,特に TBA(HTBA) を用いたときフェードオメーター 40 時間照射してす全 
芳香族ボリェステルーナミドおよびポリェステルーヒドラジドの耐光性と難㜣性

Table 2. Synthesis and properties of aromatic polyester-hydrazidese)

\begin{tabular}{|c|c|c|c|c|}
\hline Polymer structure ${ }^{b)}$ & $\begin{array}{l}\eta_{\left(\mathrm{nn}^{0}\right)} \\
(\mathrm{d} / \mathrm{g})\end{array}$ & Color & Flammabilityd) & Light-fastness's) \\
\hline TBA/IPDH-IPC & 0.6 & White & SE & 4 \\
\hline - $\quad-\mathrm{TPC}$ & 1.0 & . & . & 5 \\
\hline HTBA/IPDH-IPC & 0.5 & " & . & 4 \\
\hline$\therefore \quad$-TPC & 0.7 & $"$ & . & 5 \\
\hline TBS/IPDH-IPC & 0.5 & . & . & 3 \\
\hline - $\quad$-TPC & insol. & Pale brown & . & 3 \\
\hline HTBS/IPDH-IPC & 0.6 & White & - & 3 \\
\hline - TPC & insol. & Pale brown & . & 3 \\
\hline BA/IPDH-IPC & 0.5 & White & Combustion & 4 \\
\hline BS/IPDH-IPC & 0.5 & " & . & 4 \\
\hline
\end{tabular}

a) Solvent, NMP/HMPA (1/1); acid acceptor, pyridine; polymerization time, $3.0 \mathrm{~h}$. b) Mole ratio of bisphenol/IPDH was $1 / 9$. e) $0.5 \mathrm{~g} / 100 \mathrm{ml}$ in DMSO at $30^{\circ} \mathrm{C}$. d) Determined by match test of thin films (about $30 \mathrm{~g} / \mathrm{m}^{2}$ ). SE means self-extinguishing. क) The number shows the grade of light-fastness (fade-O-meter $40 \mathrm{~h}$ ). 1, dark yellow or brown; 2, yellow; 3, light yellow; 4, pale yellow; 5, no change.

Table 3. Flammability of polyester-hydrazide (TBA/IPDH-T) prepared by the two-step polymerization

\begin{tabular}{|c|c|c|c|c|c|}
\hline \multirow{2}{*}{$\begin{array}{l}\text { Polymer composition } \\
\text { (mole ratio of TBA) } \\
\text { (mol \%) }\end{array}$} & \multicolumn{2}{|c|}{ Bromine content } & \multirow{2}{*}{$\begin{array}{l}\text { Match test of film } \\
\qquad\left(30 \mathrm{~g} / \mathrm{m}^{2}\right)\end{array}$} & \multicolumn{2}{|c|}{ LOI } \\
\hline & $\begin{array}{l}\text { Found } \\
\text { (wt \%) }\end{array}$ & Calcd & & $\underset{\left(30 \mathrm{~g} / \mathrm{m}^{2}\right)}{\text { Film }}$ & $\begin{array}{c}\text { Filter paper } \\
\left(300 \mathrm{~g} / \mathrm{m}^{2}\right)\end{array}$ \\
\hline 0 & - & - & Combustible & $21.0 \sim 21.5$ & $24 \sim 25$ \\
\hline 3 & 2.90 & 2.86 & Combustible $\sim \mathrm{SE}$ & $22.0 \sim 22.5$ & $26 \sim 27$ \\
\hline 5 & 4.69 & 4.68 & 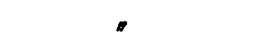 & 23.5 & $27 \sim 27.5$ \\
\hline 7 & - & 6.42 & $S E^{b)}$ & 24.5 & $30 \sim 30.5$ \\
\hline 10 & 8.90 & 8.89 & $"$ & $24.0 \sim 24.5$ & $31 \sim 31.5$ \\
\hline HTBA/IPDH(1/9)-T & 8.10 & 8.05 & , & $24.0 \sim 24.5$ & $26 \sim 27$ \\
\hline MPA-I") & - & - & " & $24.0 \sim 25.0$ & $33 \sim 34$ \\
\hline
\end{tabular}

a) Poly (m-phenyleneisophthalamide). b) Self-extinguishing.

く黄変が見られず，涌光性が著しく改善されたことがわ かった。一方, 篗然性に成してはBrを計算値として8〜 9 wt \% 含ませれば，自己消火性を示し，ボリマー構造 にはあまり影震されていない。たたし Br を含まないビ スフェノール $\mathbf{A}(\mathbf{B A})$ やビスフェノール S(BS)を用いた ボリエステルーヒドラジド耐光性は传れているが，い ずれる可然性となっている. したがってこの程のポリマ 一で自己消火性を得るには，Br の上らな難然性を付与 ナる元来の柴入が不可久と思われる.

本研究の目的とする耐光生の良い非溶融性, 難然性の 慗材として，TBA をビスフェノール成分とし， IPDH をジヒドラジト成分として TPC (または IPC) との共 重合体 [TBA/IPDH-T(または T)] が取も好ましい組合 せであると判断した.

そこで TBA/IPDH-T といら組成で TBA の量, 䓂 い奐えれば Brの是をどのくらいにすれば自己消火性が

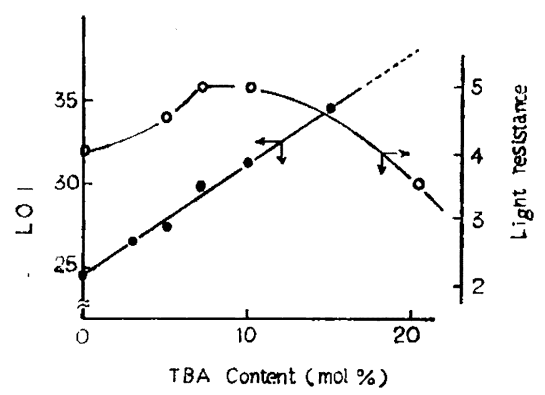

Fig. 1. Flammability and Light-fastness of polyester-hydrazide.

The weights of samples for LOI measurement were about $300 \mathrm{~g} / \mathrm{m}^{2}$.

得られるがついて枱郡した結果を Table 3 上Fig. 1 に示す. 
Table 4. Two-step polymerization of various polyester-hydrazide

\begin{tabular}{|c|c|c|c|c|}
\hline \multicolumn{3}{|c|}{ Polymer structure ${ }^{a)}$} & \multirow[b]{2}{*}{ Polymer solution } & \multirow[b]{2}{*}{$\begin{array}{l}\eta_{s_{n} h^{b)}} \\
(\mathrm{d} l / g)\end{array}$} \\
\hline Bisphenol & Dihydrazide & $\begin{array}{c}\text { Acid- } \\
\text { chloride }\end{array}$ & & \\
\hline$-\infty$ & IPDH & TPC & Colorless clear & 2.55 \\
\hline$\Rightarrow$ & , & IPC & " & 1.46 \\
\hline TBA & " & TPC & " & 2.25 \\
\hline . & , & IPC & " & 1.13 \\
\hline HTBA & " & TPC & " & 1.97 \\
\hline , & " & IPC & " & 1.20 \\
\hline TBS & " & TPC & Pale yellow clear & 2.09 \\
\hline BA & " & " & Colorless clear & 2.36 \\
\hline HQ & " & " & Pale yellow clear & 1.85 \\
\hline
\end{tabular}

2) The mole ratio of bisphenol/IPDH was $1 / 9$. b) $0.5 \mathrm{~g} / 100 \mathrm{~m} / \mathrm{DMSO}$ at $30^{\circ} \mathrm{C}$. c) One-step polymerization.

Fig. 1，Table 3 の結果から見ると TBA の含有锤に 比例して LOI 伯も高くなり, 十分なる自己消火性を得 るには 7 10 mol \% の TBA (Brにして 6 9 wt\%) を含有させればよいことがわかった。

LOI 値も武料の形態により異なり,フィルム $\left(30 \mathrm{~g} / \mathrm{m}^{2}\right)$ と沪紙状試料 $\left(300 \mathrm{~g} / \mathrm{m}^{2}\right)$ での值を Table 3 に示したが, 形態別に上る美漠倠然性がよくなるほど大きくなる傾向 を示しているが，全体としてフィルムの方が然えやす い.このことは厚手のものよりも, 薄手のものの方が, 火災に対する危険性の高いことを示している.

また，酎光性沉いてみると，IPDH-T のホモポリマ 一よりもコボリマーの方がむしろ優れている. しかし， TBA 成分が $15 \mathrm{~mol} \%$ を越えると逆にホモボリマーよ りも悪くなり，5 10 $\mathrm{mol} \%$ の领域が最も耐光性が優れ ていた.

一方，非浴蛼性に闺しては，溶飄することも滴下する 現象もなく満足できるものと思われた。ただ，ビス〉 ェノールとして $10 \mathrm{~mol} \%$ の HTBA を用いたときは 滴下することはないがやや溶骶する現象が珰められた。

以上の結果から, 耐光性, 難然性のともに得九た非溶 融性の菜材として，TBAを 7 10 mol\% 含有した芳 香族ポリエステルーヒドラジドが見いだされた．更に二 段重台法で，種々のビスフェノールを用いた芳香族ポリ エステルーヒドラジドを合成した結果を Table 4 に示し たが，いずれも非常に高粘度のものが得られた。
胡辞 本研究の発表について御助言をいただきまし

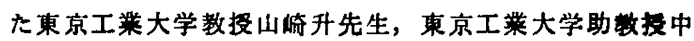
捠精一先生，また本研究の発表を餉可して下さいました

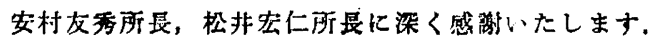

\section{文献}

1) L. K. McCune, Text. Res. J., 32, 762 (1962); du Pont, 特公昭 35-13247; du Pont 特公昭 35-14399 など.

2) M. Day and D. M. Wiles, Text. Res. J., 44, 888 (1974).

3) J. F. Krasny, et al., U. S. Government Research Development Reports AD No. 759217 (1972).

4) 田中伊都郎, 加藤克彦, 渡辺一椎, 高分子綸文 集, 36, 713 (1979).

5) A. H. Frazer and F. T. Wallenberger, $J$. Polym. Sci., Part A, 2, 1137 (1964).

6) 久世勝朗, 三輸怡, 工金化学雑誌, 71, (No. 3), 443 (1968); Tod. W. Campbell, et al., J. Appl. Polym. Sci., 2 (No. 5), 155 (1959); 化学大辞典, 共立出版社, 東京 (1968) なと.

7）帝人，特開沼 48-71495。 
Light-Fastness and Flammability of Aromatic Polyester-Amide and Polyester-Hydrazides*

Itsuro TANAKA*1, Kazuo WATANABE*2, and Katsuhiko KATO*3

*Studies on Flame-Resitant Fibers. V.

*1 Toyobo Co., Ltd. Tokyo Branch (17-9, Nihonbashi, Koami-cho, Chuo-ko, Tokyo, 103 Japan)

*:Toyobo Co., Ltd. Katata Research Center (1300-1, Honkatata-cho, Ootsu, 520-02 Japan)

*3 Toyobo New York Inc. (245, Park Avenue, New York, N.Y. 10017 U.S.A.)

In order to obtain a flame-resistant fiber having excellent light-fastness and non melting, bromine was introduced into aromatic polyester-amides and polyester-hydrazides, by copolymerization. It was found that the polyester-hydrazide composed of terephthaloyl dichloride, isophthaloyl dihydrazide and 2, 2-bis(3, 5-dibromo-4-hydroxphenyl) propane (tetrabromo-bisphenol A) with 6 9wt $\%$ of bromine content , gave satisfactory results and had a great potential as an excellent flame-resistant fiber. Two step polymerization was devised to obtain a polymer having moleculer weight sufficiently high for spinning process; tetrabromobisphenol $\mathbf{A}$ was first allowed to react with terephthaloyl dichloride in a halogenized hydrocarbon solvent and then isophthaloyl dihydrazide was added to react with the first step products in a polar organic solvent at low temperature. The maximum value of $\eta_{\operatorname{lnh}}$ of polyester-hydrazide was 2.25 .

KEY WORDS Aromatic Polyester-Hydrazide / Light-Fastness / Flammability / Terephthaloyl Dichloride / Isophthaloyl Dihydrazide / Tetrabromobisphenol A /

(Received December 27, 1978: Accepted May 21, 1979)

[Kobunshi Ronbunshu, 36 (11), 721-727 (1979)] 